\title{
BRICS and Sovereign Internationalism
}

Richard Sakwa

\begin{abstract}
The article outlines four types of globalism contending for hegemony today. The struggle of what effectively represents different types of international order is one reason why international politics today looks so disordered. The BRICS association is firmly located as part of one of these orders, that of sovereign internationalism, but is challenged by the disruptive implications of the Trumpian mercantilist order. BRICS and its members as a result are drawing closer to the liberal internationalist model. However, this is made more difficult by liberalism's shift towards some of the Trumpian exclusionary agenda. Despite some inner contradictions, the BRICS is one of the institutional and normative cornerstones of sovereign internationalism.
\end{abstract}

\section{Models of globalism}

Four types of globalism have shaped international politics in the post-1945 era. The first is the US-led liberal international order, based on an expansive dynamic of universal rules and economic interactions. This has been the most vigorous international order of the modern era, transforming much of the world in its image. The liberal international order combines military, economic and political sub-orders, each operating according to a specific dynamic but coalescing to create a polymorphic and energetic international order. Kissinger argues that the vitality of an international order depends on the balance it strikes between legitimacy and power, with both subject to evolution and change. However, he warns, 'When that balance is destroyed, restraints disappear, and the field is open to the most expansive claims and most implacable actors; chaos follows until a new system of order is established'. 'The Versailles settlement in his view placed excessive emphasis on the legitimacy component and the appeal to shared values, and by ignoring the element of power effectively provoked German revisionism. ${ }^{2} \mathrm{~A}$ similar problem applies today, when the balance within the liberal international order is increasingly shifting towards the power component, as seen in various sanctions regimes. This is a symptom of the larger shift in the post-Cold War era when the liberal international order effectively claimed to be synonymous with order itself. The international system as a whole from this perspective came to be seen as the extension of domestic politics into the international domain. In the post-communist era this gave rise to what can be called democratic internationalism. ${ }^{3}$ In other words, after 1989 , both the power and the legitimacy components of liberal internationalism became radicalised and thereby undermined its claims to hegemony.

The second type of globalism is the one represented until 1991 by the Soviet Union and its allies, which for a time in the 1950s included China. The Soviet Union from the beginning represented an unstable combination of socialist nationalism and revolutionary internationalism, but with the consolidation of Stalin's rule the former predominated. With 
the disintegration of the Soviet bloc in 1991, the challenge of revolutionary internationalism largely disappeared, although there remain some echoes of the old model in the international system today. At the same time, new sources for the impetus for the revolutionary renewal of the international system are emerging today, notably the climate emergency. This demands new forms of social organisation and a thorough rethinking of growth-led models of economic development. In the end, a new form of revolutionary internationalism may be the only answer to the survival of humanity on this planet.

The third type of globalism, which is gaining increasing traction today, is the transactional and mercantilist approach adopted by Donald Trump. It is far from limited to him, and national populism is the fastest growing political movement of our time. ${ }^{4}$ For Trump the international sphere is simply the extension of the market into the larger domain, where the zero-sum logic predominates and in which there is a ruthless battle for market share. The weakest go to the wall, while the strong become stronger. There is no room for multilateral agencies or international alliances, which in Trump's view only constrains the US. Values are humbug, everything is transactional, and there is no need for democracy promotion. This is a stark model of Westphalian internationalism, harking back to an earlier era before 1914 when the first era of globalisation came into contradiction with statist Social-Darwinism. The national interests of sovereign states predominated, and in part the First World War represented a revolt against the erosion of state sovereignty by market relations. Today, this logic is reprised in the arguments of radical Brexiteers in the UK, and in the sovereigntist movements in continental Europe, notably in Marine Le Pen's National Rally in France, Thierry Baudet's Forum for Democracy in the Netherlands and Matteo Salvini's Northern League (La Liga) in Italy. Like Mussolini, Salvini moved from left to right, arguing 'Ironically, I see more leftist values in the European right than in some left-wing parties; these parties and these movements are those that today defend workers, those who lead right battles. Thus, I do not see anything strange in looking for a dialogue with whoever today embodies the resistance to this wrong Europe'.

The fourth type of globalism is the one now associated with Russia and China and its BRICS allies.This model of conservative internationalism emphasises the importance of sovereign decision-making by nation states, but it also understands the importance of internationalism. As in the two-level European Union, where the Commission and its agencies exercise elements of supra-nationalism while the member states retain large areas of autonomy in decision-making, so the international system in this sovereign internationalism model operates on two levels. The top 'floor', level as it were, is the sphere of what the English School calls the 'secondary' institutions of international society, including the United Nations and the whole ramified network of international legal, economic, environmental and social governance, which has developed enormously in the post-war era. Many of these bodies were sponsored by the liberal globalists, but exponents of this fourth model of globalism insist that these bodies do not, as it were, belong to them. As far as sovereign internationalists are concerned, drawing in part on the Yalta principles defended by the Soviet Union, they belong to all of humanity. At the ground level there are the competing states, representing the type of globalism defended by Trump and his ilk, for whom the institutions of global governance are little more than a nuisance. ${ }^{6}$ The international system as a whole is still far from the model represented by the EU, but sovereign internationalists recognise the importance of global governance institutions to manage economic and social processes, and increasingly to deal with the crisis of global warming. Their internationalism is more than instrumental, although defenders of this position are certainly not willing to cede extensive supranational powers to international society. We are still a long way from creating a world government, but there remains a constant dynamic (as in the EU) between the two levels. 
No model is sealed from the others, and there is a constant tension and interplay between the imperatives of the liberal, revolutionary, mercantilist and conservative forms of globalism. None is hermetically sealed from the others, yet four distinctive principles are at play, and each represents a unique perspective on the international system. Moreover, theoretical models act as political maps, and in our case this suggests the possibility of crosscutting alliances. As we shall see, the disruptive challenge of national populism pushes conservative internationalists towards greater solidarity with liberal internationalists, since both seek to defend multilateralism and the top level international organisations. However, such an alliance is incapacitated by the radicalised power dimension of the US-led liberal international order.

\section{New regionalism and the BRICS}

It is within the framework of the model of international affairs represented by sovereign internationalism that the BRICS develops. Already in 1996 the veteran Soviet diplomat and scholar and then Russian foreign minister, Yevgeny Primakov, presented a plan to bring together the RIC countries of Russia, India and China to foster multipolarity. ${ }^{7}$ In November 2001, Jim O'Neil, a leading economist at Goldman Sachs, published a research paper in which he added Brazil to the earlier RIC to make BRIC, the acronym which lasted until South Africa formally joined the group in December 2010 to make it BRICS. ${ }^{8}$ O'Neil was writing from an emerging markets perspective, and assessed the countries in terms of their potential as investment opportunities and the potential of their stock markets. Vladimir Putin took up the Primakov challenge, and in June 2006 the group was formally established, and the first formal session was a gathering of BRIC finance ministers in New York in September 2006. Putin then hosted the first BRIC summit in Yekaterinburg in June 2009, and since then BRICS summits have been held annually. Today the BRICS encompass 30 per cent of the earth's landmass, 43 per cent of global population, 46 per cent of the global labour force, and with 30 per cent of global GDP, surpasses the EU or the US as the single largest community of its kind in the world. The BRICS countries hold 40 per cent of global foreign exchange reserves -31 per cent belonging to China alone. The BRICS' share of global trade rose from 7 per cent in 2001 to 17 per cent in 2015, and by 2040 it is estimated that it will account for a greater share of global GDP than the original G7 combined. ${ }^{9}$

BRICS is a loose association of countries that share certain interests, but it is not a formal alliance or even an organisation. ${ }^{10}$ Nevertheless, the depth of normative congruence should be stressed, focused on creating a more plural, and thereby in their view, a more legitimate international system. ${ }^{11}$ This includes support for reform of the UN Security Council to ensure greater representation from the global south. The association is not so much South-South, but represents a powerful East-South bloc to rival the hegemony of the North. The body brings together both developed and developing countries, and has, for example, a coordinated strategy in the World Trade Organisation (WTO) to create a fairer order concerning agricultural policies. Developing countries have long sought the liberalisation of the international economic order, complaining that agricultural subsidies in the US and the EU distort the market to the detriment of third world producers. BRICS has also taken the lead in coordinating discussions over climate change, although it maintains a low profile in security questions - this is the prerogative of the Shanghai Cooperation Organisation (SCO), to which the leading members of BRICS also belong. The initiative 'reflected more the perceived inability of the global economic order in satisfying their respective interests and needs, than the strength of common BRICS views'. ${ }^{12}$

The BRICS have created parallel structures, including a shift away from dependence on the Western financial system. ${ }^{13}$ The gridlock in IMF and World Bank reform puts 
'multilateralism at risk' ${ }^{14}$ IMF reform in particular has been an arduous process. The G20 Seoul Summit in 2010 reallocated voting rights to reflect the new global economic realities, but ratification was held up by the US Congress and only came into effect in January 2016. The cumulative quota for emerging markets and developing countries (EMDCs) rose by 2.1 per cent from 36.6 to 38.7 per cent. BRICS and EMDCs continued to press for further substantive quota formula review. ${ }^{15}$ The failure to adequately reform the Bretton Woods financial institutions - the World Bank and the International Monetary Fund - prompted the development of an alternative financial architecture. Russia and China increasingly settle energy trades in roubles and yuan. As the era of sanctions intensifies, with China increasingly in the frontline along with Russia, both countries have rapidly de-dollarised to reduce their vulnerability to US pressure. There is still a long way to go, but the direction of travel is clear.

The South Africa BRICS summit in 2013 agreed to create a New Development Bank (NDB), which was formally launched at the Fortaleza summit in Brazil in June 2014. The NDB is headquartered in Shanghai and became operative in 2016, headed by the Indian economist Kundapur Vaman Kamath. The NDB finances infrastructure projects and plans to switch from the US dollar to a basket of currencies. Threats to remove Russia from SWIFT accelerated the establishment of the Mir bank payment system, a domestic version of Visa and MasterCard, accompanied by moves to create alternatives to the Bank for International Settlements (BIS) and the IMF. A Contingent Reserve Arrangement (CRA) was launched at the seventh BRICS summit in Ufa on July 8-9, 2015 to provide a financial safety net in the event of a financial shock or crisis in the balance of payments of a member state. It provides an outlet for China's foreign currency reserves as an alternative to US government bonds. This reflects China's economic predominance, representing over 60 per cent of aggregate BRICS GDP.

In this way the 'non-West' began to develop a parallel set of financial structures. Given the disparate nature of the countries involved, this is accompanied by the incorporation of China's earlier 'peaceful rise' rhetoric to become the leitmotif of the group as a whole. This stresses that the BRICS are not directed against anyone but is beneficial for all. This was accompanied by the argument that, unlike the Western 'teachers of humanity' (as Putin put it in his famous Munich speech of February 2007), the BRICS do not try to force its solutions on other countries. This is in keeping with the philosophy of sovereign internationalism. All the BRICS countries are conservative when it comes to preserving their sovereignty, but they all recognise the value of international cooperation (although Brazil under the presidency of Jair Bolsonaro from January 1, 2019 veered towards the Trumpian mercantilist model). This was clearly formulated by Vadim Lukov, Russia's ambassador-at-large, who argues that BRICS has four strategic goals:

"First, each BRICS member wants to pursue an independent policy line on the world stage; second, we all want a reform of the global financial system, reforming the IMF in the first instance; third, we want to strengthen the role of the UN and the primacy of law in international relations; and fourth, we want to use the factor of complementarity of our economies to speed up these economies' development."16

China and India are the only BRICS countries that have registered consistent growth over the last three decades. India's population ( 1.25 billion) is second only to China's ( 1.4 billion), but its economy is five times smaller. Despite its size, India lacks a permanent seat in the UNSC and is a relative pygmy in world affairs. ${ }^{17}$

China needs BRICS neither for trade nor security reasons, but stresses that it provides a framework for cooperation that increases stability in the international system. In other 
words, BRICS, as well as the SCO, provides an adequate formula for the implantation of the 'internationalist' part of the sovereign internationalist formula. This also applies to Russia, with the added dynamic of attempts to ensure that Eurasia retains sovereign autonomy in global affairs. Opening the combined BRICS and SCO meeting on July 9, 2015at Ufa with the leaders of the other Eurasian Economic Union (EEU) states in attendance, Putin noted that,

"For us this [the Eurasian landmass] isn't a chessboard, it's not a geopolitical playing field - this is our home, and all of us together want our home to be calm and affluent, and for it not to be a place of extremism or for attempts to protect one's interests at the expense of others."

This was an explicit rebuke to Brzezinski's conceptualisation of Eurasia as the field for a renewed great game. ${ }^{18}$ Putin went on to argue that the two organisations as well as the EEU 'In many ways share similar traditional values, common laws of morality, truth and justice'. He then went on to outline what was in effect the programme of the non-West:

"We are united in the sense that the aims that have been set can only be achieved by acting collectively, on the basis of genuine partnership, trust, equal rights, respect and acknowledgement of each other's interests. We call for the drawing-up of coordinated responses to global challenges, for the affirmation of just foundations for contacts between states, with the UN playing a key role, based on international law, the principles of indivisibility, security and peoples freely determining their own destiny". ${ }^{19}$

The combined meeting was unprecedented, bringing together a good part of humanity, including the leaders of 15 states from various continents. The Goa BRICS summit of October 15-16, 2016 revealed divisions, with China refusing to support an Indian motion condemning alleged Pakistani terrorism, but the Goa Declaration condemned 'unilateral military interventions and economic sanctions in violation of international law and universally recognised norms of international relations'. It was dedicated to 'building responsive, inclusive and collective solutions', ${ }^{20}$

The grouping amplifies the weight of the member states in the international system and creates a discursive space for an alternative model of international relations. Although there are clear differences in emphasis, overall the meetings symbolised the emergence of a powerful new voice in global affairs. The BRICS group is a powerful expression of sovereign internationalism. The movement is post-Western to the degree that the main drivers of this model of the international system are located in the South and East, but the model is also attractive to many in the West. It offers a dynamic and normatively convincing alternative to a dangerously radicalised liberal internationalism and a dangerously reactionary national populism, especially in its Trumpian form.

\section{Neo-revisionism: the politics of resistance}

The financial and other crises buffeting the Western world after 2008 revived the orthodox Soviet belief in the inevitable decline of the West. The 2015 Valdai Club briefing materials argued that 'The world is standing at a parting of the ways: will the internal problems of the leading countries and the growing strength of the non-Western centres bring us to a revolutionary explosion or will changes be slow and systematic'. The dominance of the West was acknowledged, but two trends undermined the status quo: 'the relative decline of 
America's allies, from the EU to Japan; and the narrowing of the gap between them and BRICS countries in terms of influence on global processes'. The document rejected the view that a 'revolutionary demolition of the Western-centric global order' was on the cards, arguing that there was 'still scope for orderly reform', but for Russia, 'interdependence is turning into a source of pressure and vulnerability'. ${ }^{21}$ The response was to insulate Russia from external duress by creating an alternative framework of international governance while reinforcing traditional instruments of diplomacy and great power behaviour.

Russian thinking tends to exaggerate the pace of Western decline, yet there are profound shifts in the balance of global power. The Russian Foreign Policy Concept of February 12, 2013 argued that the EEU and the BRICS states would strengthen and ultimately eclipse the historical West, whose influence was declining. ${ }^{22}$ Russia stands accused of trying to force the pace of the West's decline by undermining the liberal international order through various forms of asymmetrical attacks. ${ }^{23}$ Russia and the West entered a danse macabre in which each anticipated the demise of the other. The BRICS alignment, as we have seen, does seek a greater role in global economic governance, but eclipse is not an immediate prospect. However, the BRICS group is part of an anti-hegemonic alignment that reprises some of the arguments of the Non-Aligned Movement. Russia and China are at the heart of this movement, while India since independence has exemplified the policy of sovereign internationalism by carefully balancing between the great powers. Postapartheid South Africa has also been committed to pursuing a sovereign path of development, and has avoided becoming entangled in security alliances. It is only Brazil that is defecting from its traditional position and is moving into the Trumpian national-populist camp. Nevertheless, the anti-hegemonic formulation remains a powerful force in international politics. It is no less ambitious than the ideological conformations of the Cold War, and has a far greater chance of being realised.

After 1989 only one model of international affairs was assumed to be viable, so the emergence of alternatives shocked defenders of the liberal international order. The militaryindustrial component soon rallied behind the Trumpians to face down the unexpected threat. This is why the US National Security Strategy of December 18, 2017 warned against the 'revisionist powers of China and Russia'. ${ }^{24}$ But what does revisionism mean in the current international context? Is Russia really out to destroy the foundations of world order as it has taken shape since 1945? Rather than being a full-fledged revisionist power, a better term to describe Russia's ambition, and that of the BRICS alignment as a whole, is 'neo-revisionism'. This reflects their dissatisfaction with how international affairs are currently run, but it does not mean that the Kremlin and its allies are out to destroy the international system as it is presently constituted. The idea is to change the practices rather than the principles of the current international order. The fact of American primacy is accepted, either through exercising 'leadership' in the liberal international order, or through 'greatness' in the Trumpian mercantilist model. America's overwhelming military and economic predominance is recognised, but this does not mean, as far as Moscow is concerned, that all other states have to accept a diminished role in international affairs. Russia's fundamental demand is to become an accepted co-manager of international affairs. It is on this terrain of sovereign internationalism that the current battle lines are drawn.

Neither Russia nor China will accept a position of subaltern globalism. The idea of neorevisionism fits into Russia's view of the international system as a whole. Russia, like China, accepts the normative order represented by the institutions of international legal, economic and security governance in what we call the 'top floor' of the system, above all the United Nations. Both countries seek certain reforms of the top floor institutions, including the way that the Bretton Woods institutions are constituted and run, but neither, or their allies, are out to destroy them. As the threat of actual and potential sanctions has increased, both countries have 
accelerated the drive to outflank some of these bodies, above all by creating an alternative network of financial institutions. The idea is to insulate themselves from the burgeoning sanctions regime. This alternative architecture at present is not destructive of the old institutions, although they may in the end render elements of the old order redundant.

Neo-revisionism in this context means, first, the reassertion of interests, typically couched in the language of sovereignty, and thus repudiates the unmediated universalisation of the US-led liberal international order. Both Moscow and Beijing reject the idea that the definition of their national interests can in some way be outsourced to an external power, or that concern over the patterns of power and authority in their neighbourhoods is somehow illegitimate. Second, the idea that the US-led liberal international order is synonymous with order itself is rejected. This entails an ambitious attempt to universalize universalism. The idea is to free the top level institutions from their perceived instrumental subordination to the US-led Atlantic power system. Third, on simple empirical grounds, Moscow and Beijing point out that this 'order' is at best extremely disordered, in part as a result of the radicalisation of that order after 1989. Attempts at nation-building following regime change have invariably been catastrophic. It does not take a strategic genius to see that the hubristic assertion of the power of the Atlantic alliance has been at best misdirected and at worst folly. Russia in particular, faced by the relentless onward march of NATO to its borders and into the Balkans, believes that within the benign carapace of globalisation there lies an aggressive globalist power system.

The choice ultimately is between subordination and resistance - and Moscow in the end chose the latter. This gave rise to the theoretical grounding for this resistance, which in the end comes down to a simple formula - anti-hegemonism. American primacy could by and large be accepted as a fact of life, but the assertion of hegemony by definition means the return of some sort of neo-containment strategies vis-à-vis Russia and China, and this was unacceptable to both. John Mearsheimer locates this struggle in a realist framework and predicts the inevitability of war between the US and China. ${ }^{25}$

\section{The new globalism and multipolarity}

However, this is becoming a broader conflict. Russia and China form the core of a nascent but rapidly developing anti-hegemonic alignment. It is not (yet) an alliance, and there are some profound tensions between the two countries; yet in international affairs today they stand shoulder-to-shoulder in their rejection of hegemonism. This powerful proto-alliance based on elements of normative convergence now stands as a combined counter-balance to the US, and more broadly to the Atlantic powers as a whole. In the long sweep of history, this antihegemonic alignment threatens the 500-year predominance of the Atlantic powers. ${ }^{26}$

As the economic centre of the world's gravity shifts from the Atlantic to the Pacific basin, so is a power transition taking place. Russian strategic thinking typically formulates this as multipolarity (or as they put it, polycentrism). It is never quite clear whether this is something to be achieved as part of an active strategy - to increase the voice of former subaltern powers- or it is becoming an objective reality through the natural rebalancing of power in the international system. Russia is reconstituting itself as a great power, China is reemerging to claim the position it once held before the rise of the Atlantic power system as the world's number one economy, and India, Brazil and some other powers are claiming a stronger voice in international affairs.

Multipolarity is the centrepiece of Russia's vision of international politics, but Moscow is challenged to advance a more positive and substantive alternative model of world order and this is where bodies such as the BRICS and the SCO fit in. Their normative model aligns with the Chinese notion of 'community of common destiny' based on 'win-win' relationships in international diplomacy. Sceptics scoff at these notions, but when they are reinforced by the 
grandiose investments envisaged by the Belt and Road Initiative (BRI), they demand greater attention. China is finally leveraging its economic might into a political ordering project. ${ }^{27}$ This will undoubtedly unsettle the existing balance of power and alliance networks.

There is another fundamental question that needs to be addressed. Russia is a former superpower that is unlikely to regain its former glory, while China is a re-emerging power that is confident of achieving far more than ever before, but both are neo-revisionist. Does this mean that neo-revisionism is little more than the prelude to full-scale revisionism, or does it suggest that both are ready to accept suboptimal outcomes? Revisionism here means not only challenging the existing balance of power and the structures of the international system, but also the ability to generate norms and to impose rules. To that extent neo-revisionism by definition contains elements of revisionism; but the 'neo' element should not be downplayed. It is a revisionism that is tempered by acceptance of power realities and constrained by selfimposed limitations.

\section{BRICS as part of the politics of alternatives}

What does this mean in practice? How does the BRICS' strategic vision of being both part of the international system while challenging some of its practices, translate into policy? Russia in particular does not challenge the rules of international order as they were formulated after 1945, but questions the way that they are interpreted and applied (the instrumental universalism mentioned earlier). While normatively clear, this nevertheless gives rise to much confusion in interpreting Russia's goals and ambitions. Is it setting itself up as some sort of alternative to the US-led liberal international order? Or does it simply want to be a complement to that order? What is the intent behind the anti-hegemonic alignment with China? Is it, as critics suggest, a coming together of two authoritarian systems, an 'alliance of autocracies', to shield themselves from Western criticism, or do they have something positive to offer? The responses are not consistent or unambiguous, but BRICS is part of the answer. It represents a demand for pluralism in the international system and repudiates what is perceived to be the instrumental universalism of the liberal international order. It is an appeal not only for multipolarity but also for a multi-order world. ${ }^{28}$ The combination of sovereignty and traditional internationalism is the normative core of the neo-revisionist line. ${ }^{29}$

Primakov was the first major leader, as foreign minister and then prime minister, who formulated the main aspects of a politics of resistance. This comprised a number of elements. First, he brought the concept of multipolarity back out of the cupboard, and it was immediately recognised for what it was - the foundational idea for a return to the late Soviet logic of 'peaceful coexistence', whereby different social systems or political orders would compete but not necessarily come into conflict. In the framework of the concepts applied in this article, this means the clash of four models of world order. Second, this was reinforced by a bold-strategy of alliance-building with non-Atlantic powers. Primakov as noted, forged the first iteration of the Russia-India-China (RIC) alignment, which in later years would become the core of the BRICS association. The BRICS group, together with the SCO, has been described as the harbinger of the 'post-Western' world. ${ }^{30}$ This is true to a point, but as suggested earlier, it is perhaps better to formulate this as a post-hegemonic world: no single model of world order can currently successfully claim to be universal. Third, Primakov prefigured many of the ideas advanced by his successors in the various BRICS capitals when it comes to issues of sovereignty and models of national economic development combining statism and the market. Not surprisingly, Primakov is one of the few post-communist leaders commanding widespread respect in the RIC countries.

The 'anti-hegemonic' BRICS and SCO are at the heart of the politics of alternatives as part of the development of multipolarity. They represent a turn away from the Atlantic power 
system, but with the potential to transform the historical West. Neo-revisionism represents the demand for the sort of negotiations that did not take place at the end of the Cold War. ${ }^{31}$ It rejects the unmediated enlargement strategy of the Atlantic system, but it seeks to work within the framework of the existing international system to transform the West. It is not about territorial aggrandisement or the repudiation of international law, but when pushed, it will fight back against what it perceives to be the aggressive revisionism of the Atlantic system. The BRICS advocacy of a plural international system is attractive to many. Old-style Gaullists, for example, always aspired to render the EU into an authority on par with the US, even though lacking its hard power. China of course was Russia's natural ally in its antihegemonic aspirations. Many in what had formerly been known as the 'third world', particularly participants of the Non-Aligned Movement, also have sympathy with attempts to balance US leadership with alternative sources of authority. This ultimately is the significance of the BRICS association.

This is not to suggest that BRICS does not face some major challenges. William Wohlworth notes that exaggerated ideas about the BRICS and other associations critical of the US-led global order have been knocked back. This was 'a narrative closely connected to the idea of the rapid return of a true multipolar system with roughly equal states at the top', but this has 'suffered setbacks'. The BRICS countries find themselves in doldrums, while expectations of China's ability to act as a global superpower have been over-estimated. The EU had been considered the heart of an 'expanding liberal order', but it is now in deep crisis. In short, in his view a new equilibrium is emerging, in which the US remains pre-eminent but China and Russia assert their interests along with a range of other actors. In the long-term 'it is hard to make the case that underlying trends clearly favour either the liberal West or the non-liberal major powers'. Only the rise of India could change the balance. The background conditions suggest a 'live-and-let-live equilibrium between the US-led West and the rest'. ${ }^{32}$ This is a sensible corrective to exaggerated views about changes in the global balance of power, while at the same time recognising the genuine shifts.

We may add that the various crises afflicting Brazil and South Africa are forcing the original Primakovian RIC countries closer together. They now meet regularly in SCO summits and on the sidelines of G20 meetings. This is accompanied by a new activism by China in international politics. China had long tried to avoid taking responsibility for managing global affairs, but Xi Jinping's ascension to the Chinese leadership marked a shift that rapidly gathered pace. ${ }^{33}$ At the Davos World Economic Forum (WEF) on January 17, 2017, Xi led a large delegation. His landmark speech argued that China could take the lead in globalisation, usurping America's role as the defender of free trade: 'Pursuing protectionism is like locking oneself in a dark room', he said. 'Wind and rain may be kept outside, but so is light and air'. ${ }^{34}$ He stressed:

"We will strive to build a new model of major country relations with the United States, a comprehensive strategic partnership of coordination with Russia, a partnership for peace, growth, reform and among different civilizations and a partnership of unity and cooperation with BRICS countries." 35

The WEF founder, Klaus Schwab, noted that Xi's presence was 'a sign of the shift from a unipolar world dominated by the US to a more multipolar system'. ${ }^{36} \mathrm{In}$ a speech in December 2016 the Chinese foreign minister, Wang Yi, mentioned 'global governance' nine times, not challenging the US geopolitically but calling for a thorough reform of the instruments of economic governance in the crucial spheres of finance, trade and investment, energy, and development. $^{37}$ 


\section{Conclusion}

This is no longer the bipolar globalism of the post-war years, or the unipolar system of the first post-Cold War quarter century, but a plural world in which international society (the institutions of global political and economic governance) are reclaimed as the patrimony of humanity. The BRICS countries seek to reshape globalism for the common good. A disparate but nevertheless strengthening tide of anti-hegemonic arrangements and organisations is emerging. This is nothing as formalised or intense as its counterpart during the Cold War, since Russia lacks the attractive power, ideological conviction or economic resources of the USSR. Equally, it makes no sense for countries wilfully to antagonise the Atlantic powers, with whom they are tied by so many trade and political relations. Nevertheless, the dangers of unipolarism are clear, accompanied by wars of choice. The creeping universalism of American law and practices of universal jurisdiction represents a new type of power that threatens the sovereignty of states everywhere. In response, anti-hegemonic movements gain vitality and dynamism.

The emergence of alternatives, institutionalised in particular in the BRICS and allied movements, can be interpreted as the struggle between various models of world order. This article has identified four, understood as ideal types. The liberal international order is challenged by the other three, but some cross-cutting alliances by their exponents are emerging. National populists ultimately represent a threat to both the liberal and the sovereign internationalists, and this is why Xi supported liberal internationalism at the 2017 Davos WEF meeting. Equally, BRICS-type sovereign internationalists can live with a deradicalised version of liberal internationalism more generally. The Trumpian disruption is a symptom of domestic dissatisfaction with traditional patterns of globalisation, but the emergence of the BRICS is no less a symptom of this dissatisfaction at the global level. All three models are challenged by the climate emergency, and despite the Trumpian denial of the urgency of the crisis, new revolutionary responses are increasingly on the agenda.

\section{Notes}

${ }^{1}$ Henry Kissinger, World Order: Reflections on the Character of Nations and the Course of History, Allen Lane, London, 2014, p. 66.

${ }^{2}$ Ibid., p. 83.

${ }^{3}$ The term comes from Nikolai Sokov, 'The Putin-Trump Summit: In Helsinki, Three Worldviews Will Clash', The National Interest, July 15, 2018 at https://nationalinterest.org/feature/putin-trumpsummit-helsinki-three-worldviews-will-clash-25766, last accessed September 2, 2019.

${ }^{4}$ Roger Eatwell and Matthew Goodwin, National Populism: The Revolt against Liberal Democracy, Pelican, London, 2018.

${ }^{5}$ Allessandro Madron, 'Lega, il salto di Salvini: Dai Comunisti padani all'amicizia con l'estrema destra', Il Fato Quotidiano, December 15, 2013 at https://www.ilfattoquotidiano.it/2013/12/15/lega-ilvoltafaccia-di-salvini-dai-comunisti-padani-allamicizia-con-lestrema-destra-ue/813511/, last accessed September 2, 2019.

${ }^{6}$ For analysis of this two-level model, see Richard Sakwa, Russia against the Rest: The Post-Cold War Crisis of World Order, Cambridge University Press, Cambridge, 2017, pp. 38-68.

${ }^{7}$ For an Indian account, see Navin Doshi, 'Primakov: the Man who Created Multipolar World and BRICS', Nalanda International, July 2015 at https://nalandainternational.org/primakov-the-man-whocreated-multi-polar-world-and-brics-by-navin-doshi/, last accessed September 2, 2019.

${ }^{8}$ Jim O'Neil, Building Better Global Economic BRICs, Goldman Sachs Global Economics Paper No. 66, New York, November 2001 at http://www.goldmansachs.com/our-thinking/archive/archivepdfs/build-better-brics.pdf. The idea was further developed in a paper by Dominic Wilson and Roopa Purushothaman, Dreaming with the BRICs: The Path to 2050, Goldman Sachs Global Economics 


Paper No. 99, New $\quad$ York, $\quad$ October 2003 at

http://avikdgreat.tripod.com/InterestingReads/BRIC_GoldmanSachs.pdf.

${ }^{9}$ Shashi Tharoor, 'BRICS and their Soft Power', Rising Powers in Global Governance: Opinion, December 20, 2016 at http://risingpowersproject.com/brics-soft-power/.

${ }^{10}$ Kwang Ho Chun, The BRICs Superpower Challenge, Ashgate, Farnham, 2013.

11 Oliver Stuenkel, The BRICS and the Future of Global Order, Lexington Books, London and Lanham, MD, 2015.

12 Andrea E. Goldstein, 'China's G20 Presidency: Coming at the Wrong Moment', in Alessia Amighini (ed.), China Dream: Still Coming True?, Italian Institute for International Political Studies (ISPI), Milan, 2016, p. 87.

${ }^{13}$ Marin Katusa, The Colder War: How the Global Energy Trade Slipped from America's Grasp, John Wiley \& Sons, London, 2014.

${ }^{14}$ Jakob Vestergaard and Robert H. Wade, 'Still in the Woods: Gridlock in the IMF and the World Bank Puts Multilateralism at Risk', Global Policy, 6 (1), February 2015, pp. 1-12.

${ }^{15}$ RISS Report, The IMF Quota Formula Review: Opportunities for BRICS and Developing World, Russian Institute for Strategic Studies, Moscow, August 2016.

16 Dmitry Babich, 'BRICS Summit in Ufa', The BRICS Post, July 8, 2015 at http://thebricspost.com/brics-summit-in-ufa-yoga-for-putin-finance-for-crimea-stability-for-theworld/.

${ }^{17}$ Sanjaya Baru, 'India and China in a multipolar world', The Hindu, May 11, 2015 at http://www.thehindu.com/opinion/lead/sanjaya-baru-writes-india-and-china-in-a-multipolar-

world/article7190817.ece.

${ }^{18}$ Zbigniew Brzezinski, The Grand Chessboard: American Primacy and its Geostrategic Imperatives, Basic Books, New York, 1997.

19 'Putin says Eurasia's not a chessboard, it's our home', Interfax, July 9, 2015 at http://russialist.org/interfax-putin-says-eurasias-not-a-chessboard-its-our-home/.

20 'Goa Declaration at $8^{\text {th }}$ BRICS Summit', October 16, 2016 at http://www.mea.gov.in/bilateraldocuments.htm?dt1/27491/Goa+Declaration+at+8th+BRICS+Summit.

${ }^{21}$ War and Peace in the $21^{\text {st }}$ Century: A New International Balance as the Guarantee of Stability, Materials for Discussion at the $12^{\text {th }}$ Annual Meeting of the Valdai Discussion Club, Sochi, October 19-22, 2015, p. 1. The final report was published as War and Peace in the $21^{\text {st }}$ Century: International Stability and Balance of the New Type, Valdai Discussion Club Report, January 2016 at http://valdaiclub.com/publications/reports/international-stability-and-balance-of-the-new-type/, p. 2.

${ }^{22}$ KontseptsiyavneshneipolitikiRossiiskoiFederatsii, MFA, February 18, 2013, http://www.mid.ru/brp 4.nsf/0/76389FEC168189ED44257B2E0039B16D. The English version is available as Concept of the Foreign Policy of the Russian Federation at http://archive.mid.ru//brp 4.nsf/0/76389fec168189ed44257b2e0039b16d.

${ }^{23}$ Mitchell A. Orenstein, The Lands in Between: Russia vs. the West and the New Politics of Hybrid War, Oxford University Press, New York, 2019; Timothy Snyder, The Road to Unfreedom: Russia, Europe, America, Tim Duggan Books, New York, 2018.

${ }^{24}$ National Security Strategy of the United States, December 2017, p. 25 at https://www.whitehouse.gov/wp-content/uploads/2017/12/NSS-Final-12-18-2017-0905.pdf

${ }^{25}$ John J, Mearsheimer, The Tragedy of Great Power Politics, updated edition, W. W. Norton, New York, 2014, originally published 2001.

${ }^{26}$ These are the arguments advanced by Amitav Acharya, The End of American World Order, Polity, Cambridge, 2014.

${ }^{27}$ As predicted by Giovanni Arrighi, Adam Smith in Beijing: Lineages of the Twenty-First Century, Verso, London, 2009.

${ }^{28}$ Trine Flockhart, 'The Coming Multi-Order World', Contemporary Security Policy, 37 (1), 2016, pp. 3-30.

${ }^{29}$ This was eloquently expressed by the Russian foreign minister, Sergei Lavrov, in his remarks to the $27^{\text {th }}$ assembly of the Council on Foreign and Defence Policy, Moscow, April 13, 2019 at http://www.mid.ru/en/press_service/minister_speeches/-

lasset_publisher/7OvQR5KJWVmR/content/id/3613993. 
${ }^{30}$ Oliver Stuenkel, Post-Western World: How Emerging Powers are Remaking Global Order, Polity, Cambridge, 2016.

${ }^{31}$ For a recent analysis, see Angela Stent, Putin's World: Russia against the West and with the Rest, Twelve, New York, 2019.

${ }^{32}$ William Wohlforth, 'Live-and-Let-Live Equilibrium: Best Option for the $21^{\text {st }}$ Century World', Valdai Discussion Club, August 16, 2016 at http://valdaiclub.com/news/live-and-let-live-equilibrium/.

33 The debates are perceptively analysed by Alexander Lomanov, 'Kitai: rastushchee ponimanie global'noi rolii otvetstvennosti', in V. V. Mikheev and V. G. Shvydko (eds), Transtikhookeanskaya bezopasnost': ierarkhiya sily i otvetstvennosti, IMEMO RAN, Moscow, 2016, pp. 48-81.

${ }^{34}$ Larry Elliott and Graeme Wearden, 'China Can Take Lead on Globalisation as US Retreats under Trump, Says Xi', Guardian, January 18, 2017, p. 18.

35 'President Xi Speech to Davis in Full', January 17, 2017 at https://www.weforum.org/agenda/2017/01/full-text-of-xi-jinping-keynote-at-the-world-economic-

forum; Tom Miles and Stephanie Nebehay, 'Xi Portrays China as Global Leader as Trump Era Looms', Reuters, January 18, 2017 at http://uk.reuters.com/article/uk-china-usa-idUKKBN1522OO.

${ }^{36}$ Larry Elliott and Graeme Wearden, no. 34.

${ }^{37} \mathrm{Xie}$ Tao, 'Assessing the China Challenge for Trump's Presidency', Carnegie-Tsinghua, January 18, 2017 at http://carnegieendowment.org/2017/01/18/assessing-china-challenge-for-trump-s-presidencypub-67690.

Richard Sakwa is Leading Researcher at the International Laboratory on World Order Studies and the New Regionalism at National Research University Higher School of Economics; Professor of Politics at the University of Kent. R.Sakwa@kent.ac.uk 